\title{
SISTEM INFORMASI KEUANGAN PADA DINAS PERHUBUNGAN KABUPATEN LOMBOK TENGAH BERBASIS WEB
}

\author{
Mohammad Taufan Asri Zaen ${ }^{1}$, Julkarnain ${ }^{2}$, Maemun Saleh ${ }^{3}$ \\ 1,2Program Studi Sistem Informasi, STMIK Lombok \\ ${ }^{3}$ Program Studi Teknik Informatika, STMIK Lombok \\ Jln. Basuki Rahmat No.105 Praya Lombok Tengah 83511 \\ ${ }^{1}$ opanzain@gmail.com, 2julkarnain.uwais.alqoroni@gmail.com, ${ }^{3}$ saleh16semb@gmail.com
}

\begin{abstract}
The Financial Information System at the Central Lombok District Department of Transportation is currently not running optimally, data processing that still involves many employees, has the consequence of increasing operational costs and requires a lot of time and funds. This study analyzes the existing problems and then designs applications that can facilitate the financial reporting.

An application that is web-based that accommodates receipts, management of the Money Usage Plan (RPU) data, creation of the expenditure accountability letter reports. This application is also used for data search and financial reporting automatically.

The financial information system in the Central Lombok District Department of Transportation can provide convenience in managing financial reporting, reducing paper usage, and time used more quickly and accurately. This application is very helpful in the financial reporting process
\end{abstract}

Keywords: Information Systems, Financial Information Systems, Information, Systems Web Based Finance

\begin{abstract}
Abstrak
Sistem Informasi Keuangan pada Dinas Perhubungan Kabupaten Lombok Tengah saat ini belum berjalan optimal, pengolahan data yang masih melibatkan banyak karyawan, memberikan konsekuensi menambah biaya operasional serta membutuhkan banyak waktu dan dana. Penelitian ini menganalisis pokok-pokok permasalahan yang ada dan kemudian merancang aplikasi yang dapat memudahkan dalam pelaporan keuangan.

Aplikasi yang dirancang berbasis web yang mengakomodir pembuatan kwitansi, pengelolaan data Rencana Penggunaan Uang (RPU), pembuatan laporan surat pertanggungjawaban belanja. Aplikasi ini juga digunakan untuk pencarian data dan pelaporan keuangan secara otomatis.

Sistem informasi keuangan pada dinas Perhubungan Kabupaten Lombok Tengah dapat memberikan kemudahan dalam pengelolaan pelaporan keuangan, mengurangi penggunaan kertas, dan waktu yang digunakan lebih cepat dan akurat. Aplikasi ini sangat membantu dalam proses pelaporan keuangan.
\end{abstract}

Kata kunci : Sistem Informasi, Sistem Informasi Keuangan, Sistem Informasi, Keuangan Berbasis Web

\section{Pendahuluan}

Saat ini Dinas Perhubungan masih menggunakan sistem Informasi Keuangan yang belum terintegrasi dengan baik. Proses pelaporan keuangan yang diawali dengan keluarnya Surat Perintah Pencairan Dana (SP2D) dari Badan Pengelolaan Keuangan
Daerah (BPKAD) ke Dinas Perhubungan yang kemudian dikelola oleh Sub-bagian Keuangan dan Perencanaan. Terkait dengan hal tersebut, semua bidang mengajukan Rencana Penggunaan Uang (RPU) ke Sub-Bagian keuangan untuk diverifikasi. Hal yang terpenting dalam proses verifikasi tersebut ialah penyesuaian jumlah anggaran yang diminta oleh bidang dengan 
anggaran/dana yang tersedia. Setelah itu, RPU yang telah diverifikasi dikembalikan ke masingmasing bidang sebagai dasar pelaporan keuangan atau dalam pembuatan Surat Pertanggung Jawaban Belanja (SPJ).

Proses pelaporan yang disebutkan diatas menimbulkan beberapa permasalahan, seperti: kurang efektif dan efisien dari segi waktu dan dana, melibatkan banyak karyawan dalam proses tersebut, yang memberikan konsekuensi menambah biaya operasional karyawan, menghabiskan kertas yang tidak sedikit.

Terkait dengan permasalahan yang telah dikemukakan pada latar belakang di atas, maka untuk memperlancar dan memudahkan proses pelaporan keuangan di butuhkan suatu Sistem Informasi Keuangan dalam bentuk Aplikasi yang mendukung hal tersebut. Pada penelitian ini akan didesain suatu sistem informasi keuangan yang berbasis Web.

\section{Tinjauan Pustaka}

Rosadi (2012), dalam penelitiannya tentang Aplikasi Pembuatan Laporan Keuangan Berbasis Web. Menghasilkan aplikasi yang dapat menjadikan dokumentasi transaksi terinegrasi dengan baik antara satu data dengan data lainnya dan dapat langsung mencetak laporan yang diinginkan dan menghasilkan laporan keuangan dengan lebih cepat dan akurat. Penelitian yang dilakukan saat ini berbeda dari sisi objek penelitian, lokasi penelitian dan proses yang berjalan [5].

Fuad dan Riayan (2013), dalam penelitiannya tentang Sistem Informasi Layanan Data Keuangan Mahasiswa di STMIK Bina Sarana Global. Menghasilkan Sistem informasi yang mempermudah pengolahan dan pengiriman data keuangan, menyediakan data keuangan dan kontribusi untuk mengembangkan layanan data keuangan kepada mahasiswa. Sistem ini menggunakan bahasa pemrograman PHP yang mendukung sistem yang akan diakses melalui internet. Sistem ini berbasis web untuk dapat mengubah sistem lama. Sistem informasi ini hanya sebatas layanan data keuangan mahasiswa, hal ini berbeda dengan sistem informasi keuangan pada dinas perhubungan yang peneliti akan rancang. Output yang akan dihasilkan juga berbeda dengan output pada sistem informasi yang peneliti rancang [7].

Yulianton, dkk (2014), dalam penelitiannya tentang Sistem Informasi Keuangan Berbasis Web untuk pengusaha kecil di Batik Wijayanti Semarang. Sistem yang dikembangkan adalah antarmuka berbasis web yang dibangun menggunakan paket perangkat lunak HTML, PHP dan MySQL. Metode pengembangan sistem ini menggunakan konsep pengembangan sistem System Development Life Cycle (SDLC). Sistem pencatatan transaksi keuangan ini mengacu pada siklus akuntansi, yang kemudian menghasilkan laporan keungan dalam bentuk: Buku Besar, Neraca, Laporan Laba/Rugi, dan Laporan Perubahan Modal. Perbedaan penelitian ini dengan yang dilakuakn oleh Heribertus Yulianton, yaitu pada lokasi penelitian dan output yang dihasilkan tidak dalam bentuk buku besar, neraca, Laporan Laba/Rugi, dan Laporan Perubahan Modal [8].

Sari (2011), dalam penelitiannya mengambil tema tentang Pembuatan Sistem Informasi Keungan Berbasis Web Pada UD.Saputra Jaya. Sistem informasi keuangan ini menghasilkan kemudahan bagi pemilik perusahaan untuk dapat menentukan laporan keuangan perusahaan apakah perusahaan laba atau rugi, juga bisa membuat laporan dari setiap masing - masing data Sisi lain dari layanan ini bisa menjadi media konsultan digital dalam menentukan pembuatan laporan keuangan yang diinginkan sesuai dengan transaksi yang terjadi. Selain pada lokasi, perbedaan penelitian ini dengan penelitian yang penulis lakukan adalah output yang dihasilkan [4].

Sistem informasi keuangan merupakan bagian dari SIM yang digunakan untuk memecahkan masalah-masalah keuangan perusahaan. Menurut Azhar Susanto (2002:68), Sistem informasi manajemen merupakan kumpulan dari sub-sub sistem yang saling berhubungan satu sama lain dan bekerjasama secara harmonis untuk mencapai satu tujuan yaitu mengolah data menjadi informasi dalam proses pengambilan keputusan saat melaksanakan fungsinya [2]. Sedangkan keuangan (Ridwan S. Sunjaja dan Inge Berlian) adalah ilmu dan seni dalam mengelola uang yang mempengaruhi kehidupan seseorang dan organisasi. Sistem informasi keuangan merupakan sub sistem dari sistem informasi manajemen yang dirancang untuk menyediakan informasi kepada orang atau kelompok baik di dalam maupun di luar perusahaan mengenai arus keuangan serta permasalahan yang terdapat dalam perusahaan tersebut [9].

\section{Metodologi Penelitian}

Metode Analisis yang digunakan adalah analisis PIECES. Analisis PIECES merupakan 
teknik untuk mengidentifikasi dan memecahkan permasalahan yang terjadi pada sistem informasi. Hanif Al Fatta (2007: 51-54) menjelaskan bahwa Analisis PIECES terdiri dari Analisis Kinerja (Performance), Analisis Informasi (Information), Analisis Ekonomi (Economy), Analisis Keamanan (Controling), Analisis Efisiensi (Eficiency), Layanan (Service) [6].

Metode perancangan yang digunakan pada perancangan sistem ini adalah metode pengembangan sistem SDLC (System Development Life Cycle) merupakan pengembangan/rekayasa sistem informasi (system development) dan atau perangkat lunak (software engineering) dapat berarti menyusun sistem/perangkat lunak yang benar-benar baru atau yang lebih sering terjadi yaitu menyempurnakan yang telah ada sebelumnya [1]

\section{Hasil dan Pembahasan}

Tabel 4.1 Analisis PIECES

\begin{tabular}{|c|c|c|}
\hline No. & Parameter & Hasil Analisis \\
\hline 1. & Performance & $\begin{array}{l}\text { Sistem yang berjalan saat ini } \\
\text { belum cukup maksimal } \\
\text { dikarenakan penyusunan RPU } \\
\text { (Rencana Penggunaan Uang) } \\
\text { dari masing-masing bidang } \\
\text { masih dilakukan manual dan } \\
\text { harus menunggu perivikasi dari } \\
\text { bendahara. Hal ini yang } \\
\text { menyebabkan terdapat } \\
\text { beberapa kendala salah } \\
\text { satunya membutuhkan waktu } \\
\text { yang kurang efesien dan } \\
\text { berakibat pada lambatnya } \\
\text { proses pelaporan keuangan. }\end{array}$ \\
\hline 2. & Inforr & $\begin{array}{l}\text { Dalam proses pencatatan dan } \\
\text { penyimpanan spj terdapat } \\
\text { kendala yang berkaitan dengan } \\
\text { informasi yang dihasilakan, } \\
\text { yaitu kurang tersedianya } \\
\text { penyimpanan yang aman dan } \\
\text { up to date, sehingga proses } \\
\text { pencarian data-data spj sering } \\
\text { mengalami kendala. }\end{array}$ \\
\hline 3 & Econ & $\begin{array}{l}\text { Nilai suatu informasi } \\
\text { ditentukan oleh dua hal yaitu } \\
\text { biaya dan mamfaat untuk } \\
\text { mendapatkan informasi } \\
\text { tersebut. Parameter dari segi } \\
\text { biaya adalah pada sistem yang } \\
\text { lama masih membutuhkan }\end{array}$ \\
\hline
\end{tabular}

\begin{tabular}{|c|c|c|}
\hline & & $\begin{array}{l}\text { waktu yang lama sehinga biaya } \\
\text { SDM juga meningkat seperti } \\
\text { kerja lembur untuk } \\
\text { menyelesaikan pekerjaan } \\
\text { pembuatan SPJ yang masih } \\
\text { dilakukan secara manual. } \\
\text { Dengan kemampuan yang } \\
\text { diberikan oleh sistem yang } \\
\text { baru secara optimal biaya yang } \\
\text { dikeluarkan relatif lebih rendah } \\
\text { karena pengolahan data dapat } \\
\text { dilakukan melalui sistem yang } \\
\text { baru. }\end{array}$ \\
\hline 4 & Control & $\begin{array}{lr}\text { Peningkatan } & \text { terhadap } \\
\text { pengendalian } & \text { untuk } \\
\text { mendeteksi atau memperbaiki } \\
\text { kesalahan serta kekurangan } \\
\text { yang akan terjadi. Pengendalian } \\
\text { atau kontrol dalam sebuah } \\
\text { sistem sangat diperlukan } \\
\text { keberadaannya r untuk } \\
\text { menghindari dan mendeteksi } \\
\text { secara dini terhadap } \\
\text { penyalahgunaan san atau } \\
\text { kesalahan sistem serta untuk } \\
\text { menjamin keamanan data atau } \\
\text { informasi yang di Dinas } \\
\text { Perhubungan. Dengan adanya } \\
\text { control, maka tugas atau kinerja } \\
\text { yang mengalami gangguan bisa } \\
\text { diperbaiki secara cepat. }\end{array}$ \\
\hline 5 & $\overline{\text { Efficiency }}$ & $\begin{array}{l}\text { Terdapat banyak arsip } \\
\text { yang menumpuk sehingga } \\
\text { memenuhi banyak tempat. } \\
\text { 2. Pembuatan laporan } \\
\text { keuangan menggunakan } \\
\text { kertas terlalu banyak. }\end{array}$ \\
\hline 6 & Service & $\begin{array}{ll}\text { 1. } & \begin{array}{l}\text { Bendahara } \\
\text { mengatur pesulitan }\end{array} \\
\text { anggaran dikarenakanan } \\
\text { usulan dari bidang yang } \\
\text { harus diverifikasi terlebih } \\
\text { dahulu. } \\
\text { 2. } \\
\text { Bagian adminstrasi } \\
\text { keuangan membutuhkan } \\
\text { banyak waktu dalam } \\
\text { pembuatan spj dan } \\
\text { kelengkapannya. }\end{array}$ \\
\hline
\end{tabular}

Dari beberapa solusi yang ditawarkan, peneliti memilih untuk membuat sebuah sistem informasi keuangan berbasis web, sehingga pengolahan data keuangan lebih efektif dan efesien. 


\subsection{Diagram alir sistem}

4.1.1. Diagram alir sistem yang diusulkan untuk bendahara username dan password benar maka admin masuk ke sistem aplikasi keuangan bagian admin.

2. Admin melakukan input data pegawai

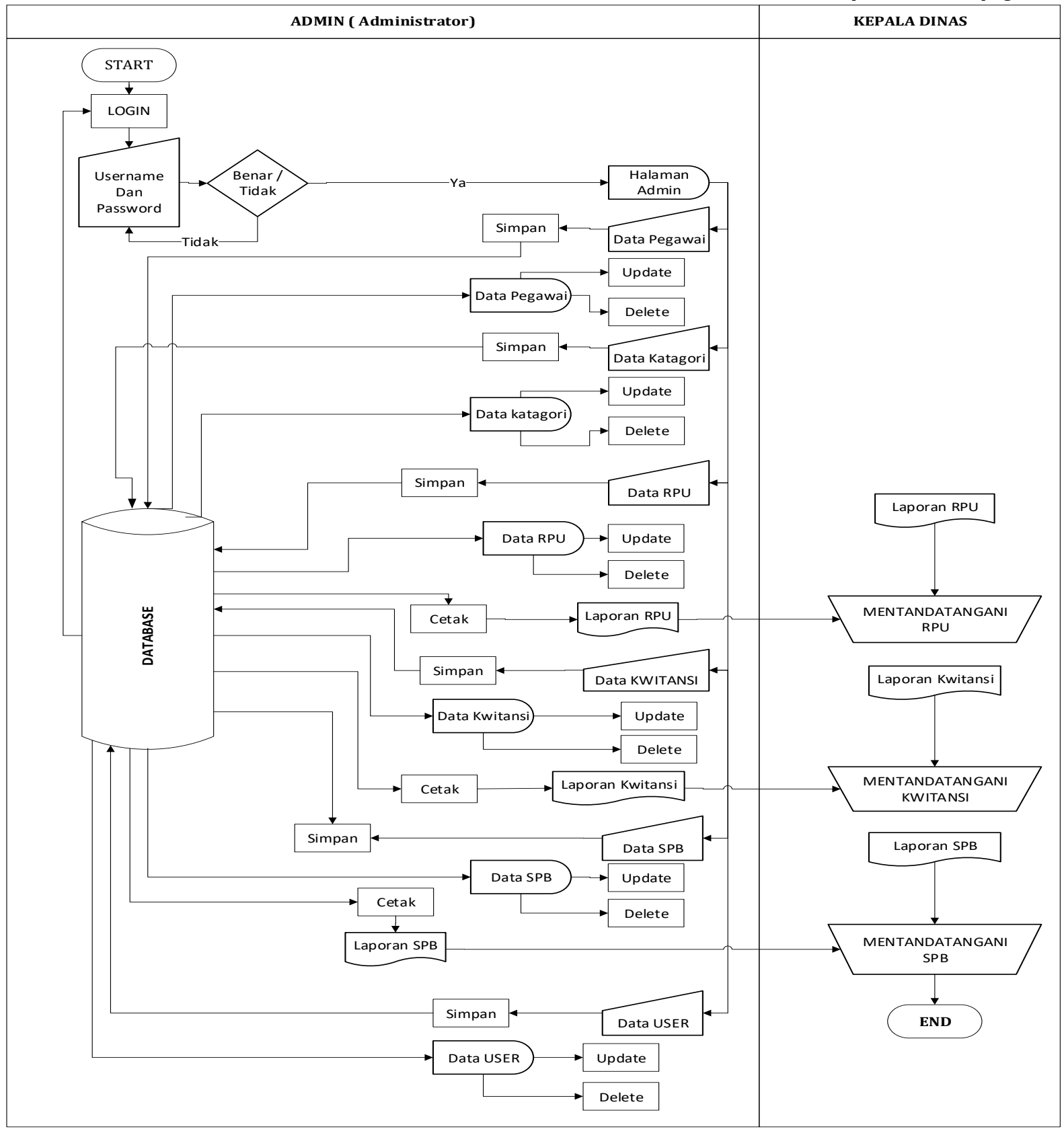

Diagram alir sistem yang diusulkan untuk bendahara, dapat dilihat pada gambar 4.1.

Berikut adalah keterangan gambar 4.1. diagram alir untuk bendahara:

1. Admin login ke sistem aplikasi keuangan dengan memasukan username dan password, jika username dan password salah maka lakukan konfirmasi login ulang dan jika kemudian disimpan dan ditampilkan pada halaman data pegawai kemudian data pegawai dapat di update dan di delete.

3. Admin melakukan input data katagori kemudian disimpan dan ditampilkan pada halaman data katagori kemudian data katagori dapat di update dan di delete

4. Admin melakukan input data $R P U$ kemudian disimpan dan ditampilkan pada halaman data 
RPU kemudian data RPU dapat di update, delete dan di cetak sebagai bahan laporan.

5. Admin melakukan input data kwitansi kemudian disimpan dan ditampilkan pada halaman data kwitansi kemudian data kwitansi dapat di update, delete dan di cetak sebagai bahan laporan.

6. Admin melakukan input data SPB kemudian disimpan dan ditampilkan pada halaman data SPB kemudian data SPB dapat di update, delete dan di cetak sebagai bahan laporan.

7. Admin melakukan input data user kemudian disimpan dan ditampilkan pada halaman data user kemudian data user dapat di update dan di delete.

Berikut adalah keterangan diagram alir untuk User:

1. User login ke sistem aplikasi keuangan dengan memasukan username dan password, jika username dan password salah maka lakukan konfirmasi login ulang dan jika username dan password benar maka user masuk ke sistem aplikasi keuangan bagian user

2. User melakukan input data pegawai kemudian disimpan dan ditampilkan pada halaman data pegawai kemudian data pegawai dapat di update dan di delete.

3. User melakukan input data RPU kemudian disimpan dan ditampilkan pada halaman data $R P U$ kemudian data $R P U$ dapat di update, delete dan di cetak sebagai bahan laporan.

4. User melakukan input data kwitansi kemudian disimpan dan ditampilkan

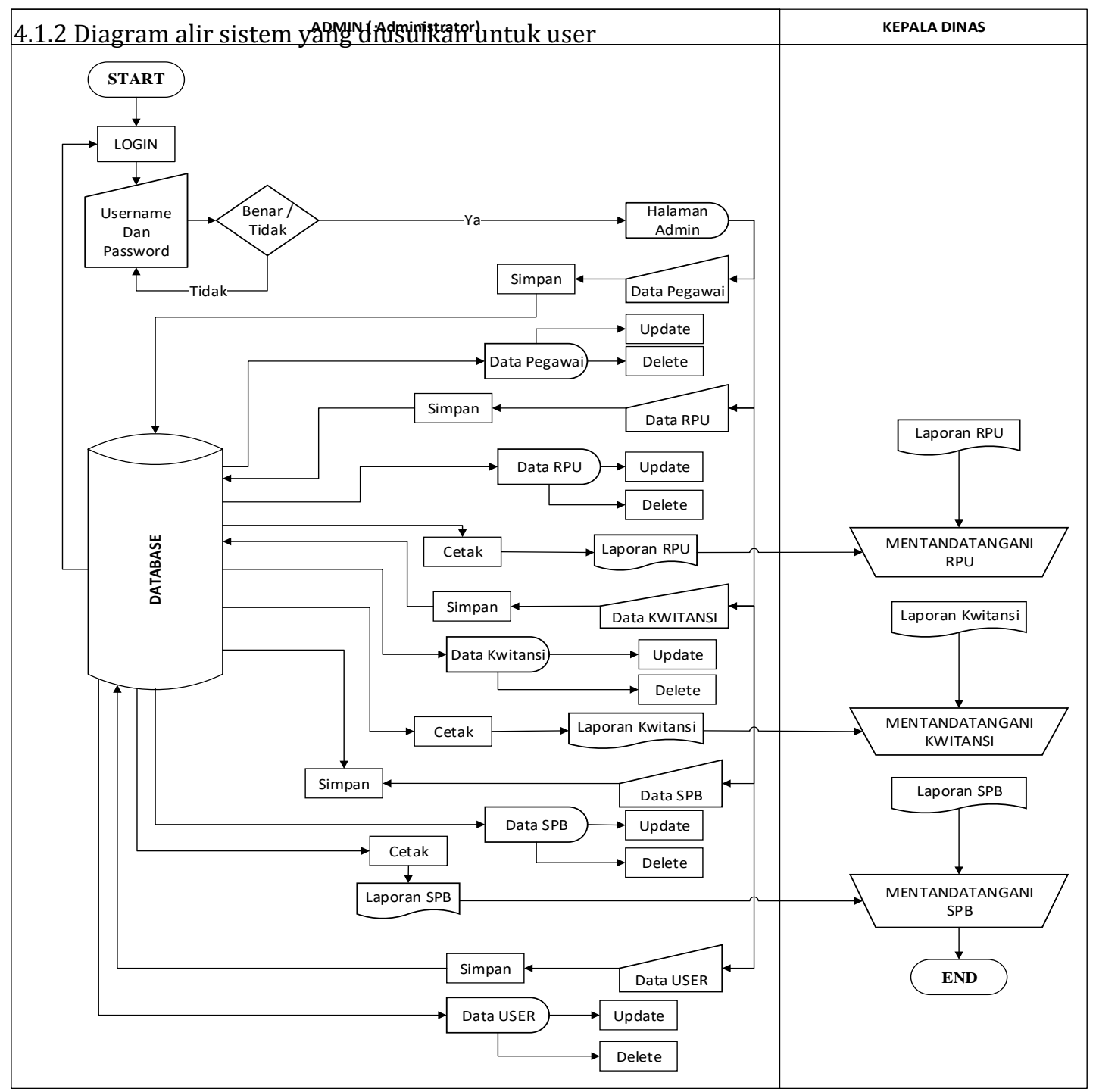

Gambar 4.2. Diagram Alir Untuk User 
pada halaman data kwitansi kemudian data kwitansi dapat di update, delete dan di cetak sebagai bahan laporan.

5. User melakukan input data $S P B$ kemudian disimpan dan ditampilkan pada halaman data $S P B$ kemudian data $S P B$ dapat di update, delete dan di cetak sebagai bahan laporan.

6. User dapat melihat data user yang sudah diinputkan oleh admin.

\subsection{Interface}

\subsubsection{Halaman Beranda}

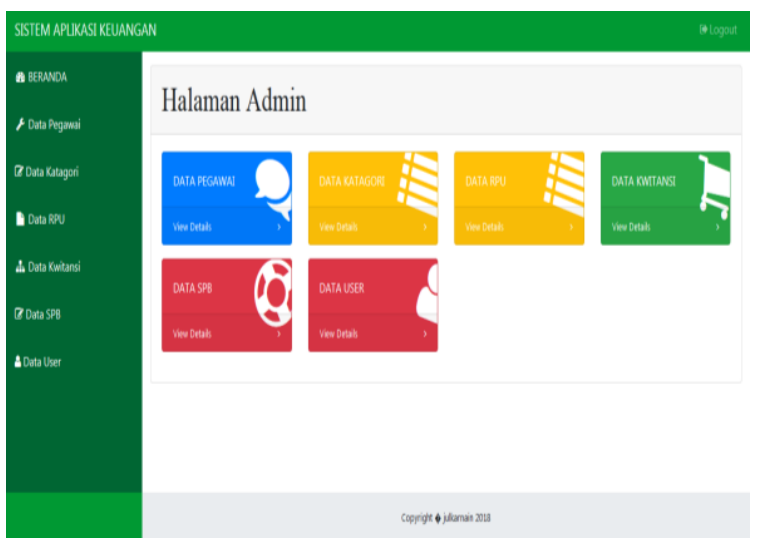

Gambar 4.3. Halaman Beranda

Didalam halaman utama admin terdapat menu beranda sebagai menu utama ketika pengguna masuk sistem aplikasi keuangan, menu data pegawai merupakan menu yang digunakan untuk melihat data pegawai yang sudah di inputkan ke dalam database. Menu data katagori merupakan menu yang digunakan untuk melihat data katagori yang sudah di inputkan ke dalam database, menu data rpu merupakan menu yang digunakan untuk melihat data rpu yang sudah di inputkan ke dalam database, menu data kwitansi merupakan menu yang digunakan untuk melihat data kwitansi yang sudah di inputkan ke dalam database, menu data spb merupakan menu yang digunakan untuk melihat data spb yang sudah di inputkan ke dalam database, menu data user merupakan menu yang digunakan untuk melihat data user yang sudah di inputkan ke dalam database dan menu logout digunakan untuk keluar dari aplikasi keuangan.
4.2.2. Halaman Data Rencana Penggunaan Uang (RPU)

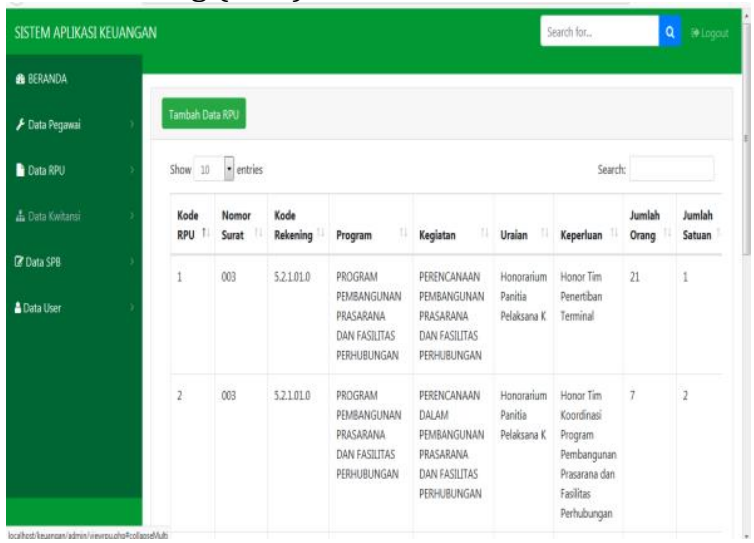

Gambar 4.4. Halaman Data RPU

Halaman data rpu merupakan halaman yang digunakan untuk melihat data rpu yang sudah di inputkan dan dihalaman data rpu terdapat tombol tambah digunakan untuk menambah data, tombol edit digunakan untuk edit data dan tombol hapus digunakan menghapus data. Untuk melakukan proses pencarian data rpu dengan memasukkan data rpu yang akan dicari, sedangkan untuk proses cetak data rpu pilih menu dropdown data rpu.

\subsubsection{Halaman Data Kwitansi}

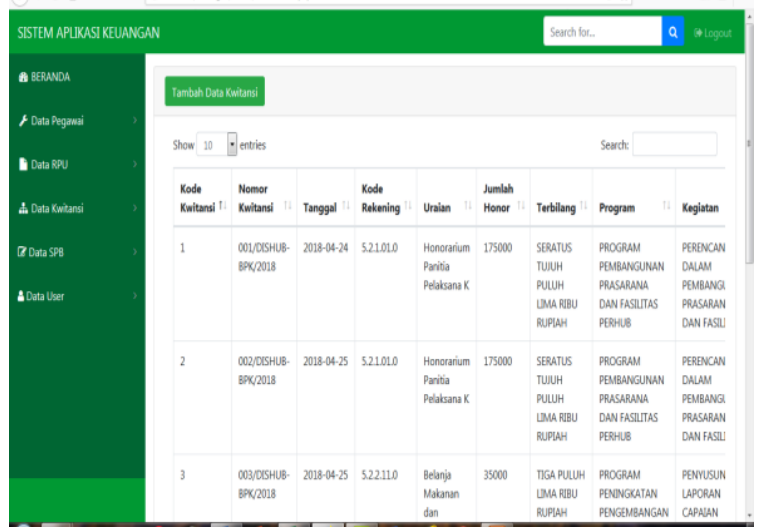

Gambar 4.5. Halaman Data Kwitansi

Halaman data kwitansi merupakan halaman yang digunakan untuk melihat data kwitansi yang sudah di inputkan dan dihalaman data kwitansi terdapat tombol tambah digunakan untuk menambah data, tombol edit digunakan untuk edit data dan tombol hapus digunakan menghapus data . Untuk melakukan proses pencarian data kwitansi dengan memasukkan data kwitansi yang akan dicari, sedangkan untuk proses cetak data pilih tombol cetak untuk cetak data kwitansi. 
4.2.4. Halaman Data Surat Tanggung Jawab Belanja (SPB)

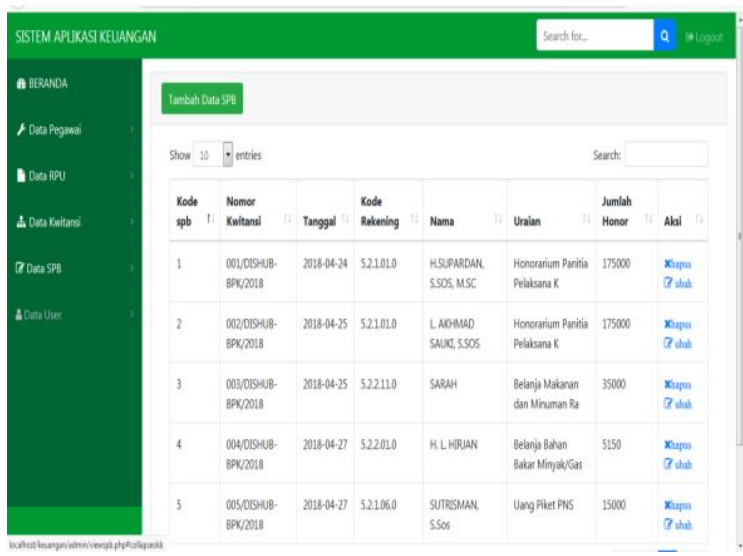

Gambar 4.6. Halaman Data SPB

Halaman data SPB merupakan halaman yang digunakan untuk melihat data spb yang sudah di inputkan dan dihalaman data spb terdapat tombol tambah digunakan untuk menambah data, tombol edit digunakan untuk edit data dan tombol hapus digunakan menghapus data. Untuk melakukan proses pencarian data spb dengan memasukkan data spb yang akan dicari, sedangkan untuk proses cetak data pilih menu laporan spb pada menu data spb.

\section{Kesimpulan dan saran}

5.1. Kesimpulan

Dengan dibangunnya sistem informasi keuangan dapat menangani masalah bagi instansi terkait dalam hal ini Dinas Perhubungan Kabupaten Lombok Tengah. Adapun penanganan masalahnya sebagai berikut :

1. Dengan adanya aplikasi sistem informasi keuangan proses pengolahan data keuangan seperti kelengkapan spj yang mencakup rpu, spb dan kwitansi lebih mudah dan cepat.

2. Pengolahan dan penyimpanan database lebih akurat dan aman

\subsection{Saran}

Berdasarkan kesimpulan di atas, diharapkan adanya pengembangan lagi dari sistem informasi keuangan ini, maka saran-saran yang dapat dikemukakan agar menjadi bahan masukan dan pertimbangan adalah sebagai berikut :

1. Sistem informasi ini hendaknya digunakan oleh admin yang memahami sistem komputerisasi, sehingga penyajian informasinya dapat dilakukan dengan lebih baik.

2. Pengolahan data keuangan dapat diperluas lagi untuk pengembangan sistem informasi yang lebih akurat.

3. Mengembangkan aplikasi ini agar dapat melakukan proses pembuatan kwitansi belanja barang.

\section{Daftar Pustaka}

[1] A. Nugroho, Analisis dan Perancangan Sistem Informasi dengan Metodologi Berorientasi Object, Bandung: Informatika, 2005.

[2] A. Susanto, Sistem Informasi Manajemen, Edisi 2, Bandung: Lingga Jaya, 2002.

[3] A.-B. b. Ladjamudin, Analisis dan Desain Sistem Informasi, Yogyakarta: Graha Ilmu, 2005.

[4] D. I. Sari, "Pembuatan Sistem Informasi Keuangan Berbasis Web Pada UD.Saputra Jaya," Jurusan Sistem Informasi STMIK AMIKOM Yogyakarta, 2011.

[5] D. Rosadi dan U. Lousiani, "Aplikasi Pembuatan Laporan Keuangan Berbasis Web," Jurnal Computech \& Bisnis, vol. 6, no. 2, pp. 96-100, Desember 2012.

[6] H. A. Fatta, Analisis dan Perancangan Sistem Informasi, Yogyakarta: Andi Offset, 2007.

[7] H. Fuad dan Riayan, "Rancang Bangun Sistem Informasi Layanan Data Keuangan Mahasiswa Studi Kasus di STMIK Bina Sarana Global," Jurnal Sisfotek Global, vol. 3, no. 2, pp. 43-49, September 2013.

[8] H. Yulianton, F. A. Sutanto dan S. Mulyani, "Rancang Bangun Sistem Informasi Keuangan Berbasis Area untuk Pengusaha Kecil (Studi Kasus Batik Wijayanti Semarang)," Jurnal Teknologi Informasi DINAMIK, vol. 19, no. 2, pp. 137-143, Juni 2014.

[9] R. S. Sundjaja dan I. Berlian, Manajemen Keuangan 2 Edisi Keempat, Yogyakarta: Literata Lintas Media, 2003

[10] W. Purnomo dan E. Damayanti, Pemrograman Web 1 Untuk SMK/MAK Kelas X, Jakarta: Kementerian Pendidikan dan Kebudayaan Republik Indonesia, 2013.

[11] W. (STMIK L. Gani, Abdul, Bagye, "Sistem Informasi Praktek Kerja Industri Pada Smk Islam Sirajul Huda Paok Dandak," J. Manaj. Inform. dan Sist. Inf., vol. 1, no. 1, pp. 52-56, 2018. 